\title{
Zaman etütleri için geliştirilen ölçüm ve kayıt araçlarının veri hassasiyeti yönünden birbirleriyle ve kronometreyle karşılaştırılması
}

\author{
Mehmet Eker ${ }^{a^{*}}$ (D), Yasin Kurt ${ }^{b}$ (i)
}

\begin{abstract}
Özet: Bu çalışmanın amacı; ormancılık işlerinde zaman etütlerinde kullanılmak üzere son zamanlarda geliştirilmiş olan android tabanlı Zaman Ölçme ve Kaydetme (ZÖKA) uygulaması ile Windows ișletim sistemi tabanlı zaman kayıt ve analiz yazılımı olan Time Analysis (TA) programını, veri hassasiyeti ve kullanım özellikleri bakımından birbirleriyle ve dijital kronometre ile karşılaştırmak ve uygulanabilirliklerini tartışmaktır. Zaman etütlerinin etkililiğini arttırmak amacıyla geliştirilmiş olan ZÖKA uygulaması ve TA programının zaman etütlerindeki performansları, kronometreye göre olumlu-olumsuz yönleri ve hangisinin daha kullanılabilir olabileceği konusundaki soruların giderilmesi için bu çalıșma gerçekleștirilmiștir. Oduna dayalı orman ürünleri üretim faaliyetleri sırasında, kızılçam (Pinus brutia Ten.) ağaç türüne ait tomruk kabuklarının motorlu testereye montajlı kabuk soyma aleti ile soyulması ișine ait çalıșma süreleri, video kaydedicilerle iș yeri zamanı ölçeğinde kaydedilmiștir. Kaydedilen görüntüler video oynatıcı yazılımlar yardımıyla izlenerek dolaylı gözlem yöntemiyle iş dilimlerine ait gerçek süreler ölçülmüş ve bunlar kontrol verisi olarak kullanılmıştır. Aynı görüntüler üzerinden aynı etütçü ile dijital kronometre, ZÖKA uygulaması ve TA programı ile zaman ölçümleri yapılarak elde edilen veriler, kontrol verisiyle ve birbirleriyle veri hassasiyeti yönünden karşılaştırılmıştır. Kronometre, ZÖKA uygulaması ve TA programına yönelik kullanım özellikleri ile bu üç aracın yapısal nitelikleri de göz önünde bulundurularak basit bir kıyaslama yapılmıştır. Kısa süreli iş dilimlerinin (3 sn ve altı) yer aldığı işlere ait zaman ölçümlerinde göz-el ve kulak-el koordinasyonuyla ZÖKA uygulamasının daha hassas veri ölçüp kaydedebildiği ve daha etkili olduğu belirlenmiştir. İş dilimi sürelerinin 5 sn' nin üzerine çıktığı ve özellikle dolaylı gözlemlerin yapıldığ durumlarda TA programının da dijital kronometreye göre daha hassas olduğu ve veri kaydedebilme üstünlügüne sahip olduğu ortaya çıkarılmıştır. Zaman etütlerinde, özellikle kısa süreli iş dilimlerinin ölçülmesi ve kaydedilmesinde ZÖKA uygulaması hassasiyetle kullanılabilir.
\end{abstract}

Anahtar kelimeler: Zaman ölçme araçları, Zaman ölçme ve kaydetme uygulaması, Time analysis programı, Dijital kronometre, Zaman etüdü

\section{Comparison of time measurement and recording tools with each other and stopwatch in terms of data sensitivity}

\begin{abstract}
The aim of the study is to compare the android-based "time measurement and recording tool" (ZÖKA) application which has been developed to be used in time studies in forestry works and the "time analysis" (TA) program, which is a Windows operating system-based time recording software, with each other and with a digital stopwatch in terms of data precision and usage characteristics. This study was carried out in order to eliminate the questions about the performance of ZÖKA and TA program developed for the purpose of time studies, their positive and negative aspects compared to the chronometer, and which one could be more effective. During the wood-based harvesting activities, the working times of the debarking work were recorded with real-time by video recorders. The recorded images were watched with the help of video player software and the actual times of the work elements (which were later used as control data) were determined by the indirect observation method. Time measurements were made on the same images with the same surveyor using a digital stopwatch, ZÖKA application and TA program. The obtained data were compared with the control data and with each other in terms of data sensitivity. A simple comparison was made by considering the usage features of the stopwatch, ZÖKA application and TA program, and the structural characteristics of these three tools. It has been determined that the ZÖKA application can measure and record more sensitive data and is more effective with eye-hand and ear-hand coordination in time measurements of jobs with short-term work periods ( 3 seconds and less). It has been revealed that the TA software is also more sensitive than the digital chronometer and has the advantage of recording data, especially in cases where the duration of the work slices exceeds 5 seconds and especially indirect observations are made. ZÖKA application can be used with precision in time studies, especially in measuring short-term work cycles.
\end{abstract}

Keywords: Time measurement tools, Time measurement and recording tool, Time analysis program, Digital stopwatch, Time studies

\footnotetext{
a Isparta Uygulamalı Bilimler Üniversitesi, Orman Fakültesi, Orman Mühendisliği Bölümü, Isparta

YK Mühendislik Ormancıllk ve Danışmanlık Hizmetleri, Denizli 


\section{Giriş}

İşlerin planlanması, yönlendirilmesi, kontrolü ve ücretlendirilebilmesi amacıyla iş etütleri yapılmaktadır (Berkel, 1976; Yıldırım, 1989; MPM, 1997; Üçüncü ve Acar, 2020). İş etüdünün iki önemli bileşeninden biri, metot etüdü ve diğeri de zaman etüdüdür (REFA, 1988; MPM,1991; Doğan, 1998; Kanawaty, 2004). Zaman etüdü; işyerinde, iş ölçümü ile birlikte çalışma zamanının ölçümü, kaydı ve analizidir. Zaman ölçümleri; işlerin gerçekleştirilmesi için gerekli olan standart çalışma zamanlarının tespit edilmesi açısından kilit rol üstlenir. Teknoloji değişimlerinde, işçilik ücretlerindeki dalgalanmalarda, mekanizasyon seviyesinin değişiminde, yeni iş basamaklarının eklenmesi veya çıkarılması ya da mevzuat değişikliklerinin olması durumunda zaman etütleri yapılmaktadır (Eker ve Kurt, 2019). İş akışı, iş çevrimleri, ölçme noktaları, ölçülecek zaman türleri, dağılım ve paylar vb. konular itibarıyla bakıldığında zaman ölçümleri emek, süre ve hassasiyet gerektirmektedir. Ormancılık bilim ve uygulamalarındaki hassas ormancılık yaklaşımı (Eker ve Özer, 2015; Gülci vd., 2015) bu tip verilerdeki hassasiyetin önemini daha da belirgin hale getirmiştir.

Ormancılık işlerinde zaman etütlerinde değişik koşullar ve amaçlar için kaydedici voltmetre ve wattmetre, kimograf (kymograph), kronosaykılgrafi (chronocyclegraph), elektronik sayıc1, Wink sayıcısı, elektrikli saat, MarstoChron makinesi, ayırıcı göstergeli kronometre ve analog kronometre gibi çeşitli niteliklerde araçlar kullanılmıştır (Aykut, 1972). 1990'lı yıllardan önce çoğunlukla farklı tipteki kronometrelerden yararlanılarak (Barnes, 1963; Björheden, 1991) ölçülen iş dilimlerine ait zaman değerleri, daha önceden hazırlanmış etüt formlarına kaydedilerek kronometraj yöntemi izlenmiştir (ILO, 1981). Klasik kronometreler, olağan zaman etütleri için yeterli olmakla beraber; teknolojinin ve çalışma koşullarının değişmesi ile çalışanın tempo ve performansının değerlendirilmesinde çeşitli tipte zaman ölçerlerin geliştirilmesine ve kullanılmasına önemli bir destek sağlamıştır (Aykut, 1972). Taşınabilir bilgisayar, kişisel bilgisayar ve cep telefonu gibi bilgisayar özellikli taşınabilir cihazların kullanımının yaygınlaşması, dijital veri girişini olanaklı kıldığından etüt karneleri yerine dijital ekranlar üzerinden ölçüm verilerinin girişi mümkün duruma gelmiştir (Leech vd., 1989; Kariniemi, 2006; Nuutinen vd., 2008; Laforest ve Pulkki, 2011). Özellikle ormancılık işlerinin zaman etütlerinde saha bilgisayarları, el (mikro)bilgisayarları ve veri kaydedicilerinin (data logger) efektif olarak kullanıldığına rastlanmıştır (Harstela, 1988; Spinelli ve Visser, 2008; Palander vd., 2013; Szewczyk vd., 2014). Öte yandan özellikle makine hareketlerine ve seslerine bağlı olarak iş adımlarını ayırt edip ona göre kayıt yapabilen otonom algılayıcılarla (sensörlerle) çalışan otomatik veri toplayıcıların kullanılmaya başlanmasıyla zaman ölçümlerinde farklı bir aşamaya gelinmiştir (Peltola 2003; Kellog vd., 2004; Nakagawa vd., 2007; Ovaskainen, 2009).

Son 20 yılda, iş etüdü araştırmalarında zaman etüdü yazılımı ile donatılmış tümleşik bilgisayar sistemleri, mikrobilgisayarlar ve dijital video görüntülerine bağlı etüt yöntemleri de yaygınlaşmıştır (Nurminen vd., 2006; Sowa ve Szewczyk 2013; Szewczyk vd., 2014; Eliasson vd., 2015). Mikrobilgisayar tarafından oluşturulan ölçümler, kronometreler kullanılarak alınan karşılaştırılabilir ölçümlerden çok daha doğru sonuçlar sunabilmiştir. Ancak gözlemlenen faaliyetlere insan tepkisindeki belirli bir gecikme ve belirli faaliyetler arasındaki ölçme noktalarını ayırt etmedeki zorluk nedeniyle veri doğruluğunun hala sınırlı olduğu da bilinmektedir (Szewczyk and Sowa, 2017).

Makineli ormancılık operasyonlarının zaman etütlerinde, makinelere montajlanmış bilgisayar sistemleri tarafından da çalışma sürelerini ölçmek mümkündür (Purfürst ve Erler 2011). Otomatik araçlarla zaman etütlerinin hassasiyetine rağmen (Mcdonald ve Fulton, 2005) tüm avantaj ve dezavantajlarıyla birlikte hala manuel yöntemlerle zaman ölçümleri devam ettirilmektedir (Peltola, 2003; Spinelli vd., 2013). Halihazırda, özellikle manuel ve yarı mekanize (motor-manuel) işlerin zaman etütleri için doğrudan veya dolaylı gözleme dayalı zaman ölçümü metodolojileri ve araçları tercih edilmektedir. Bununla birlikte manuel ya da motor-manuel işlerdeki zaman ölçümlerinde kronometraj yönteminin olumsuz yönlerinden (Üçüncü, 2005) kaçınılması ve de zaman ölçümünün daha hassas şekilde yapılabilmesi için elektronik esaslı sistemlere ihtiyaç duyulur (Eker ve Kurt, 2019). Zaman ölçüm işinin hızlandırılması, veri hassasiyetinin (kesinlik, tamlık ve doğruluk) artırılması, veri aktarımının analize hazır olacak şekilde anlık ya da hızlı-kolay biçimde aktarılması veya iletilmesi bu gereksinimi ortaya çıkarmıştır. Bu gereksinim, ormancılık işlerinin zaman etütleri için kronometre ile ölçülüp elle kaydedilen zaman ölçüm (kronometraj) teknolojisine koşut, bilgisayarlarda ve cep telefonlarında çalışan iki farklı zaman ölçme ve kaydetme aracının geliştirilmesini tetiklemiştir. Bunlardan biri, windows işletim tabanlı sistemlerde çalışan zaman kayıt, ölçme ve analiz yazılımı olan "Time Analysis (TA)" programıdır (Yılmaz, 2015). Diğeri de taşınabilir bilgisayarlar veya bilgisayar nitelikli cep telefonlarına özgün, android tabanlı bir "Zaman Ölçme ve Kaydetme (ZÖKA)" uygulamasıdır (Kurt, 2019).

$\mathrm{Bu}$ çalışmanın amacı; günümüz teknolojisiyle geliştirilen TA programı ve ZÖKA uygulaması ile klasik kronometraj (dijital kronometre ve etüt formları kullanılarak uygulanan) yöntemini; veri hassasiyeti, kullanım nitelikleri ve uygulanabilirlikleri bakımından karşılaştırmaktır. Bu çalışmanın varsayımı; ormancılık işlerindeki zaman etütlerinde, TA programı ve ZÖKA uygulamasıyla kolay, başarılı ve kronometraj yöntemi kadar hassas veri elde edilebileceğidir. $\mathrm{Bu}$ çalışmada; dijital kronometre, TA programı ve ZÖKA uygulamasının performanslarının, kızılçam tomruğu kabuklarının motorlu testereye montajlı kabuk soyma aleti ile soyulması iş aşamasının etüt edilmesiyle elde edilen kontrol (referans) verisine bağlı olarak sınanması, ormancılıktaki çeşitli işler için işlevsel ve hassas bir zaman ölçme ve kayıt aracının belirlenmesi ve bunun uygulanabilirliğinin tartışılması hedeflenmiştir.

\section{Materyal ve yöntem}

\subsection{Materyal}

$\mathrm{Bu}$ çalışmanın objesini; özellikle ormancılık faaliyetlerine yönelik zaman etütlerinde kullanılan ve kullanılabilecek zaman ölçme ve kayıt araçları (yazılım ve donanım) oluşturmuştur. Çalışmada; zaman ölçme ve kaydetmeye ve zaman analizine yarayabilecek dört farklı araçtan faydalanılmıştır. Bunlar; dijital kronometre, dizüstü bilgisayar üzerinde çalışan TA programı, cep telefonu üzerinde çalışan ZÖKA uygulaması ve tam zamanlı 
görüntü-ses kaydetme özelliğine sahip bir video kaydedici ile kaydedilen görüntülerin izlenip analiz edileceği video oynatıcı programdır. Bununla birlikte, zaman etütlerinde kullanılan; zaman etüt formu, etüt tablası ile iş ölçümü için kullanılan çap ölçer ve şerit metre çalışmada kullanılan diğer araç-gereçlerdir. Bu araç-gereçler; Isparta Uygulamalı Bilimler Üniversitesi (ISUBÜ) Orman Fakültesi, Transport ve Geomatik Laboratuvarından tedarik edilmiştir.

\section{Dijital Kronometre}

$\mathrm{Bu}$ araştırmanın gerçekleştirilmesinde; doğrudan ya da dolaylı zaman ölçümleri için kullanılmakta olan ve desimal sistemde ölçüm yapabilen $1 / 1000$ sn duyarlılıktaki, çift koşumlu ekrana sahip Kasper Richter Vario II marka ve modeldeki dijital kronometreden yararlanılmıştır (Şekil 1).

\section{TA programı}

TA programı, C Sharp yazılım platformunda üretilmiş ve daha çok masaüstü ve dizüstü bilgisayarların işletim sistemlerinde çalıştırılabilecek nitelikte bir zaman kaydetme, analiz ve sunma aracidır. TA programı, Windows tabanlı bilgisayarlar ile ikisi bir arada (2 in 1) olarak adlandirılan Windows tabanlı tabletlerde kullanılabilmektedir. $\mathrm{Bu}$ program, Yılmaz (2015) tarafından, Isparta Uygulamalı Bilimler Üniversitesi, Orman Fakültesi, Orman Mühendisliği Bölümü, Orman İnşaatı Geodezi ve Fotogrametri Anabilim Dalı'nda Lisans Tezi kapsamında geliştirilmiştir (Şekil 2).

\section{ZÖKA uygulaması}

ZÖKA, zaman ölçümü ve kaydedilmesi amacıyla açık kaynak kodlu ve özgür bir tümleşik yazılım geliştirme platformu/ortamı olan Eclipse program alt yapısı üzerinde geliştirilmiş android tabanlı bir uygulamadır. Uygulama, aktüel olarak kullanılan akıllı mobil telefonlarda çalışabilmesi için Android 2.2 froyo sürümü üzerinden konfigüre edilmiștir. Uygulamanın geliştirilmesi, android emülatörü olarak Genymotion işleçleri üzerinden sağlanmıştır. ZÖKA uygulamasının ana ekranı ve bu ekranda yer alan sekmelerin oluşturulması için açık kaynak kodlarından, kronometre yazılım mimarilerinden ve hata denetim mekanizmalarına yönelik yazılımlardan yararlanılmıștır. Donanım ve yazılım itibarıyla ortalama niteliklere sahip akıllı telefonlarda kullanılabilecek bu uygulamanın açılış ekranında 2 adet sayaç, 6 adet sabit buton ve 13 adet özelleştirilebilir işlem butonu bulunmaktadır (Şekil 3). Uygulamanın görünür ekran yapısında; toplam zamanı ve birim zamanı ölçen iki ayrı zaman sayacı, başlatma-duraklatma-devam ettirmedurdurma/sıfırlama butonları, özelleştirilebilir butonlar, ayarlar ve kaydetme butonları yer almaktadır. ZÖKA uygulaması, mobil telefona yüklenmiş vaziyetteyken tek elle kullanıma uygun niteliktedir. Mouse, mouse pad, etüt formu, etüt tablası gibi ek araçların kullanılmasını gerektirmemektedir. Bu uygulama, Kurt (2019) tarafindan ISUBÜ Lisansüstü Eğitim Enstitüsü, Orman Mühendisliği Anabilim Dalı'nda tamamlanan Yüksek Lisans tezi kapsamında geliştirilmiştir.

\section{Video kaydedici ve oynatıc}

Arazide, tomruk kabuklarının soyma operasyonlarına ait zaman ölçümlerinin kontrol verisi olarak kullanılabilmesi amacıyla; soyma iş adımının ve iş dilimlerinin kaydedilmesinde, tam zamanlı görüntü ve ses kaydetme özelliğine sahip, hafiza ve batarya kapasitesi ek donanımlarla arttırılmış Sony DCR-SX34E marka video kamera kullanılmıştır. Kaydedilen görüntüler üzerinde zaman analizi yapıp gerçek ve temel süreleri belirleyebilmek için; çalışmada kullanılan bilgisayar donanım ve yazılım özelliklerine uygun olağan video oynatıcı programlardan ve ölçülen zaman değerlerini kaydetmek için de Eker (2015) tarafından geliştirilen etüt kayıt formlarından yararlanılmıştır.

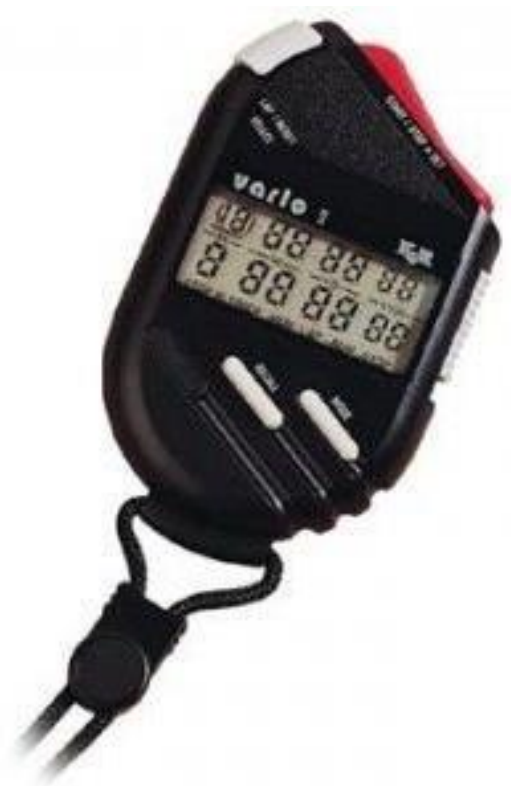

Şekil 1. Dijital Kronometre

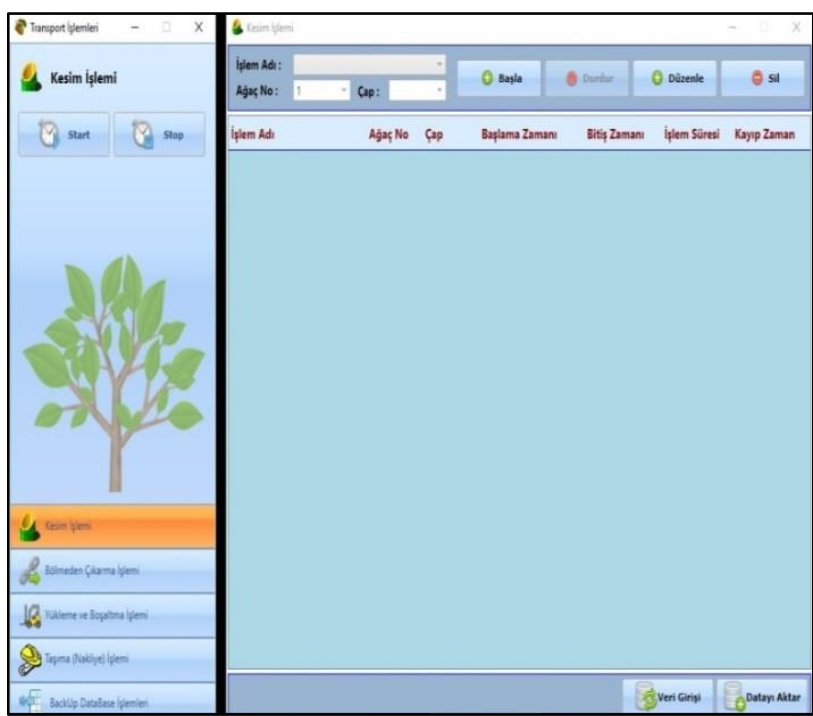

Şekil 2. Time analysis programının ana ekran görüntüsü 


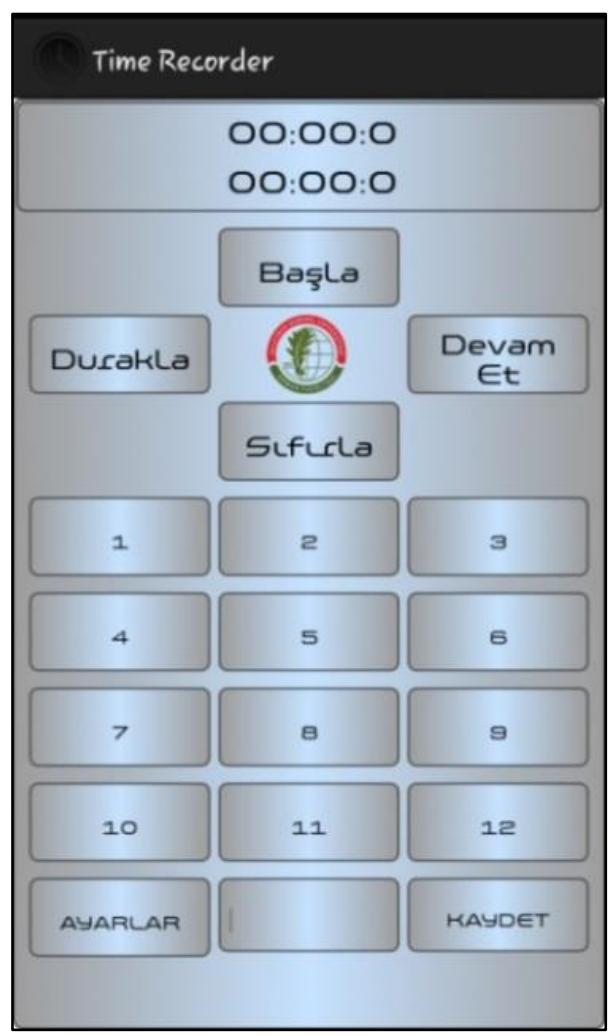

\section{Çalışma alanı ve kabuk soyma işleri}

TA, ZÖKA, dijital kronometre ve video sayacı ile elde edilen verilerin hassasiyetinin kıyaslanabilmesi için kısa süreli iş dilimleri içermesi açısından tomruk kabuklarının soyulması operasyonları, çalışmadaki iş objesini oluşturmuştur. $\mathrm{Bu}$ bakımdan, Denizli Orman İşletme Müdürlüğü'ne bağlı Sarayköy Orman İşletme Şefliği, 20182019 yıllarını kapsayan silvikültür programı kapsamında bakım çalışmalarının yapıldığı saf Kızılçam (Pinus brutia Ten.) meşceresinde, farklı çaplardaki rastgele seçilmiş 35 adet tomruk üzerinde, motorlu testereye monteli kabuk soyma aleti ile yapılan kabuk soyma işleri zaman etütlerine konu edilmiştir.

Çalışmada; ağaç kesme ve boylama operatörü (AKBO) eğitimi almış tecrübeli bir işçinin yaptığı işler etüt edilmiştir. Böylelikle aynı işçi gözlemlenerek performans ve tempo farklılıklarına bağlı olarak iş dilimlerine ait çalışma sürelerinin farklılığından kaçınılmaya çalışılmıştır. Tomruklarda, motorlu testereye monteli kabuk soyma aleti ile kabuk soyma iş akışı; kabuk soymaya hazırlık, soyma ve çevirme şeklinde 3 iş dilimi ile gerçekleştirilen bir eylem dizininden oluşmaktadır (Çizelge 1, Şekil 4).

Şekil 3. ZOKA uygulamasının ana ekranı

Çizelge 1. Kabuk soyma iş dilimleri ve ölçme noktaları (Eker ve Şefik, 2019)

\begin{tabular}{|c|c|c|c|}
\hline \multirow{2}{*}{ İş akış1 } & \multirow{2}{*}{ İş dilimi } & \multicolumn{2}{|r|}{ Ölçme noktası } \\
\hline & & Başlangıç anı & Bitiş anı \\
\hline \multirow{3}{*}{ Kabuk soyma } & $\begin{array}{c}\text { Hazırlık } \\
\text { (tomruğa yürüme/yönelme) }\end{array}$ & $\begin{array}{c}\text { Kabuk soyma işlemi için yapılacak } \\
\text { hazırlıkların başlaması }\end{array}$ & $\begin{array}{l}\text { Kabuk soyma aracının/aletinin ele alınıp tomruğa } \\
\text { yönelme ve/veya aracın kabuk soymak için çalıştırılması }\end{array}$ \\
\hline & Soyma & $\begin{array}{l}\text { Çalıştırılmış kabuk soyucu aletin ele } \\
\text { alınıp tomruğa temas ettirilmesi }\end{array}$ & $\begin{array}{c}\text { Tomruğun yüzeyinin tamamen soyulup aletin tomruktan } \\
\text { uzaklaștırılması }\end{array}$ \\
\hline & Çevirme & $\begin{array}{c}\text { Çevirmeyi sağlayacak şekilde alet ya } \\
\text { da elle tomruğa temas edilmesi }\end{array}$ & $\begin{array}{l}\text { Tomruğun kendi ekseni etrafında döndürülüp } \\
\text { sabitlenmesi }\end{array}$ \\
\hline
\end{tabular}
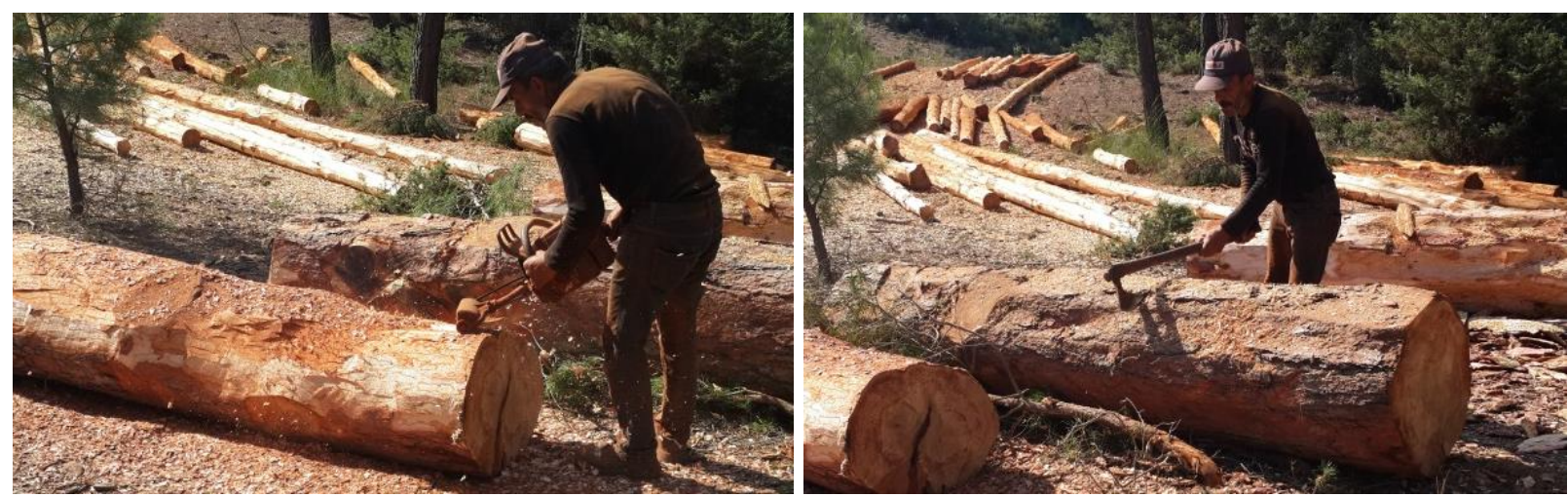

Şekil 4. Kabuk soyma aleti ile soyma (solda) ve balta ile çevirme (sağda) işleri 


\subsection{Yöntem}

Zaman ölçümlerinde kullanılabilir oldukları daha önceki çalışmalarda (Eker ve Kurt, 2019) ayrı ayrı tespit edilmiş olan TA programı, ZÖKA uygulaması ve dijital kronometrenin birbirleriyle karşılaştırabilmesi için diğer koşulların mümkün olduğunca sabitlendiği gözlenebilir/izlenebilir bir iş ortamına ve gerçek çalışma zamanlarından olan sapmaları belirleyebilmek için kontrol verisine gerek duyulmuştur. Bunun için sahada video kayıt yöntemiyle kabuk soyma işlerine ait çalışma süreleri, iş çevriminin bütününü kapsayacak şekilde tam zamanlı olarak kaydedilmiştir. Büroda bu kayıtlar açılarak (hassasiyeti başkaca saat ve kronometre ile kontrol edilen) bilgisayar saati ve video oynatıcı programın sayacı kullanılarak etüt formlarına her bir tomruğa ait iş dilimi sürelerinin başlangıç ve bitiş zamanları kaydedilerek analize hazır hale getirilmiştir. Video oynatıcı program üzerinde başlatmak, duraklatmak, geri almak, devam etmek veya durdurup yeniden başlatmak şeklinde izleme olanağı elde edildiğinden videonun zaman sayacına göre ölçülen süreler ve bilgisayar saati, sabit kabul edilerek buradan elde edilen zaman verileri, kontrol verisi yani referans değeri olarak nitelendirilmiştir. Bundan sonra da kabuk soyma işlerine ait video kayıtları her defasında baştan izlenerek adeta arazide çalışma yapılıyormuşçasına, üç farklı araçla aynı araştırmacı tarafından ayrı ayrı zaman ölçümleri yapılmıştır.

Zaman etüdünde hangi sürelerinin ölçüleceği önemli olduğundan, bu çalışmada yalnızca iş dilimlerinin ana ve yan faaliyet zamanlarından oluşan temel faaliyet zamanının (Magagnotti ve Spinelli, 2012) ölçümüne yönelik bir gözlem gerçekleştirilmiştir. Bununla birlikte, kontrol verisinin elde edilmesinde kümülatif zaman ölçme tekniğinden (REFA,1988; MPM, 1997; Yıldırım, 1989) yararlanılmıştır. Kronometre ile zaman ölçümünde, video oynatıcı program üzerinden izleme gerçekleştirilerek okunan değer, etüt formuna elle işlendiğinden burada da kümülatif zaman ölçme tekniği kullanılmıştır. ZÖKA uygulamasının kullanılmasında hem kümülatif hem de tekrarlı zaman ölçme tekniğine uyan bir ölçme sistemi kullanılabilmiştir. TA programı ise kendi butonlarına göre çalışma esasına sahip olduğundan genellikle tekrarlı zaman ölçme tekniğine uygun bir sistemle çalıştırılmıştır. Ölçme noktalarını görsel veya işitsel sinyalle algılamak mümkün olduğundan bu çalışmada, TA programı için göz-el ve gözgöz yönteminden, kronometre ile yapılan ölçmede de gözgöz yönteminden ve ZÖKA uygulamasında ise göz-el ve kulak-göz koordinasyon yöntemlerinden (Doğan, 2015; Eker ve Kurt, 2019) yararlanılarak veri kaydedilmiştir.

Kontrol verisi de dahil 4 farklı teknikle toplanan veri; Microsoft Excel programına aktarılmış ve tanımlayıcı istatistikler yapıldıktan sonra ayrı ayrı olmak üzere önce kontrol verisiyle sonra da birbirleriyle karşılaştırılmış ve aralarında veri hassasiyeti yönünden anlamlı bir farklılık olup olmadığı istatistiki olarak denetlenmiştir. 35 adet tomruk için alınan görüntü ve ses kaydı üzerinden yapılan zaman analizi sonuçlarının kıyaslaması; tomruk başına harcanan iş dilimi süreleri ile toplam sürenin ölçüm performansı esas alınarak gerçekleştirilmiştir. Bu verilerin karşılaştırılması amacıyla SPSS 22.0 programı yardımıyla ikili örneklem t-testi kullanılmıştır. İlaveten, zaman ölçme araçlarının genel özellikleri ile olumlu (avantaj; güçlü yönleri) ve olumsuz (dezavantaj; zayıf yönleri) yönleri dikkate alınarak genel bir değerlendirme de yapılmıştır.

\section{Bulgular ve tartışma}

\subsection{Video oynatıcı program sayactyla zaman analizi}

35 adet tomruğa ait kabuk soyma işinin video oynatıcı programın zaman sayacıyla ölçülmesi sonucunda elde edilen ve iş dilimlerine ait gerçek süreleri (kontrol verisini) ifade eden bulgular Çizelge 2'de verilmiştir.

Video görüntüleri üzerinden tekrarlı izleme yöntemiyle yapılan zaman etüdünde, işyeri çalışma şartları ve gözlenen operatör performansı sabitlenmiş ve zaman etütçüsünden kaynaklı zaman ölçme hataları da tekrarlı çalışmalarla en aza indirilmeye çalışılmıştır. Etütçü; ölçme araçlarını kullanırken tepki süresine, iş dilimlerinin ölçme noktasını kavramaya ve kasıtlı davranışlarından kaçınmaya azami dikkat sarf etmiştir. Elde edilen bulgularda, Çizelge 2' de görüldüğü gibi tomruk başına ortalama toplam soyma süresinin 460.24 sn olduğu ve en kısa süreli iş diliminin, hazırlık aşamasına ait olduğu belirlenmiştir. $\mathrm{Bu}$ en kısa süreli iş dilimi için ölçülen en küçük değerin, zaman ölçme araçlarının karşılaştırılmasında, bir gösterge olarak kullanılabileceğine karar verilmiştir.

\subsection{ZÖKA uygulamasiyla zaman analizi}

ZÖKA uygulaması kullanılarak video görüntüleri üzerinden 35 adet tomruğun kabuğunun soyulmasına ilişkin yapılan zaman analizi ile Çizelge 3' teki bulgular elde edilmiştir.

Çizelge 2. Video görüntülerinden ölçülen kabuk soyma sürelerine ait tanımlayıcı istatistikler

\begin{tabular}{|c|c|c|c|c|c|c|}
\hline \multirow{2}{*}{ Tanımlayıcı nitelikler } & \multicolumn{3}{|c|}{ Tomruk boyutları } & \multicolumn{3}{|c|}{ İş akış dilimlerinin zaman değerleri (sn) } \\
\hline & Orta çap $(\mathrm{cm})$ & Boy $(\mathrm{m})$ & Hazırlık & Soyma & Çevirme & Toplam \\
\hline En küçük & 20.00 & 2.00 & 3.53 & 38.43 & 18.42 & 63.07 \\
\hline En büyük & 50.00 & 3.00 & 119.52 & 533.62 & 260.60 & 862.73 \\
\hline Ortalama & 31.17 & 2.76 & 33.59 & 289.96 & 136.68 & 460.24 \\
\hline Standart sapma & 8.00 & 0.32 & 25.98 & 128.87 & 69.54 & 198.91 \\
\hline
\end{tabular}

Çizelge 3. ZÖKA uygulaması ile ölçülen kabuk soyma sürelerine ait tanımlayıcı istatistikler

\begin{tabular}{|c|c|c|c|c|c|c|}
\hline \multirow{2}{*}{ Tanımlayıcı nitelikler } & \multicolumn{3}{|c|}{ Tomruk boyutları } & \multicolumn{3}{|c|}{ İș akıș dilimlerinin zaman değerleri (sn) } \\
\hline & Orta Çap $(\mathrm{cm})$ & Boy $(\mathrm{m})$ & Hazırlık & Soyma & Çevirme & Toplam \\
\hline En küçük & 20.00 & 2.00 & 3.67 & 38.70 & 20.18 & 63.48 \\
\hline En büyük & 50.00 & 3.00 & 121.87 & 574.88 & 287.85 & 917.98 \\
\hline Ortalama & 31.17 & 2.76 & 35.25 & 311.52 & 148.37 & 495.15 \\
\hline Standart sapma & 8.00 & 0.32 & 30.48 & 138.76 & 74.74 & 213.29 \\
\hline
\end{tabular}


Çizelge 3' te görüldüğü gibi, ZÖKA uygulaması ile ölçülüp kaydedilebilen kabuk soyma iş akış dilimleri birlikte değerlendirildiğinde; tomruk başına ortalama toplam soyma süresinin 495.15 sn ve en kısa süreli en küçük iş dilimi süresinin de 3.67 sn olduğu belirlenmiştir. Bu bulgu, ZÖKA uygulamasının kısa süreli iş dilimi zamanlarının etüdünde başarılı şekilde kullanılabileceğini işaret etmektedir.

\subsection{TA programıla zaman analizi}

Aynı video kayıtları üzerinden, TA programı ile 35 adet tomruk kabuğunun soyulmasına ilişkin yapılan zaman ölçümünden elde edilen bulgular Çizelge 4' te özetlenmiştir.

TA programiyla yapılan zaman analizlerinde kabuk soyma sürecinde gözlemlenip kayda aktarılan en kısa süreli hazırlık iş dilimi için tomruk başına en küçük soyma zamanının 3.77 sn bulunması, bu programla da kısa süreli iş dilimlerine ilişkin zaman ölçümlerinin yapılabileceğini göstermiştir.

\subsection{Dijital kronometreyle zaman analizi}

Video görüntüleri üzerinden dijital kronometre ile yapılan zaman ölçümünden elde edilen bulgular Çizelge 5' te özetlenmiştir.

Bu çalışmada kullanılan çift koşumlu dijital kronometre sayesinde dolaylı gözlem yönteminin sunduğu avantajdan yararlanılarak en kısa süreli iş dilimi için 3.82 sn ölçeğinde zaman okumalarının yapılabildiği belirlenmiştir.

\subsection{Zaman ölçme araçlarının veri hassasiyeti yönünden karşılaş̧ırılması}

Kabuk soyma sürecindeki her bir iş dilimi için ölçme araçlarıyla elde edilen temel süre, hem kontrol verisi ile hem de birbirleriyle karşılaştırılmış ve özellikle kontrol verisinden olan sapmalar (+; pozitif yönlü farklar) gerçek değer ve \% değer üzerinden belirlenmiştir (Çizelge 6 - 9).

Çizelge 4. TA programı ile ölçülen kabuk soyma sürelerine ait tanımlayıcı istatistikler

\begin{tabular}{lccrrr}
\multirow{2}{*}{ Tanımlayıcı nitelikler } & \multicolumn{3}{c}{ Tomruk boyutları } & \multicolumn{2}{c}{ İs akış dilimlerinin zaman değerleri (sn) } \\
\cline { 2 - 6 } & Orta çap $(\mathrm{cm})$ & Boy $(\mathrm{m})$ & Hazırlık & Soyma & \multicolumn{2}{c}{ Toplam } \\
\hline En küçük & 20.00 & 2.00 & 3.77 & 38.67 & 20.62 \\
En büyük & 50.00 & 3.00 & 123.53 & 580.80 & 291.80 \\
Ortalama & 31.17 & 2.76 & 35.68 & 314.83 & 149.94 \\
Standart sapma & 8.00 & 0.32 & 30.80 & 139.80 & 526.75 \\
\hline
\end{tabular}

Çizelge 5. Kronometre ile ölçülen kabuk soyma sürelerine ait tanımlayıcı istatistikler

\begin{tabular}{lccrrr}
\multicolumn{2}{c}{ Tanımlayıcı nitelikler } & \multicolumn{3}{c}{ Tomruk boyutları } & \multicolumn{2}{c}{ İs akış dilimlerinin zaman değerleri (sn) } \\
\cline { 2 - 6 } & Orta çap $(\mathrm{cm})$ & Boy $(\mathrm{m})$ & Hazırlık & Soyma & Çevirme \\
\hline En Küçük & 20.00 & 2.00 & 3.82 & 38.73 & 21.03 \\
En Büyük & 50.00 & 3.00 & 124.03 & 582.42 & 295.28 \\
Ortalama & 31.17 & 2.76 & 35.96 & 316.76 & 151.11 \\
Standart sapma & 8.00 & 0.32 & 30.95 & 140.83 & 530.48 \\
\hline
\end{tabular}

Çizelge 6. Hazırlık zamanlarının kontrol verisinden olan (+) farkları

\begin{tabular}{|c|c|c|c|c|c|c|c|c|}
\hline \multirow{2}{*}{ Özellikler } & \multicolumn{2}{|c|}{ Kontrol verisi } & \multicolumn{2}{|c|}{ Kronometre } & \multicolumn{2}{|c|}{ ZÖKA } & \multicolumn{2}{|c|}{ TA } \\
\hline & sn & $\%$ & sn & $\%$ & sn & $\%$ & sn & $\%$ \\
\hline En küçük & 3.53 & 100 & 0.20 & 5.66 & 0.13 & 3.77 & 0.20 & 5.66 \\
\hline En büyük & 119.52 & 100 & 8.00 & 6.69 & 5.93 & 4.96 & 7.28 & 6.09 \\
\hline Ortalama & 33.60 & 100 & 2.36 & 7.04 & 1.65 & 4.92 & 2.08 & 6.19 \\
\hline
\end{tabular}

Çizelge 7. Soyma zamanlarının kontrol verisinden olan $(+)$ farkları

\begin{tabular}{|c|c|c|c|c|c|c|c|c|}
\hline \multirow{2}{*}{ Özellikler } & \multicolumn{2}{|c|}{ Kontrol verisi } & \multicolumn{2}{|c|}{ Kronometre } & \multicolumn{2}{|c|}{ ZÖKA } & \multicolumn{2}{|c|}{ TA } \\
\hline & sn & $\%$ & $\mathrm{sn}$ & $\%$ & sn & $\%$ & sn & $\%$ \\
\hline En küçük & 38.43 & 100 & 0.30 & 0.78 & 0.27 & 0.69 & 0.23 & 0.61 \\
\hline En büyük & 533.62 & 100 & 55.05 & 10.32 & 45.57 & 8.54 & 49.68 & 9.31 \\
\hline Ortalama & 289.96 & 100 & 26.80 & 9.24 & 21.56 & 7.44 & 24.87 & 8.58 \\
\hline
\end{tabular}

Çizelge 8. Çevirme zamanlarının kontrol verisinden olan (+) farkları

\begin{tabular}{ccccrrrrr}
\hline \multirow{2}{*}{ Özellikler } & \multicolumn{2}{c}{ Kontrol verisi } & \multicolumn{2}{c}{ Kronometre } & \multicolumn{2}{c}{ ZÖKA } \\
\cline { 2 - 8 } & \multicolumn{1}{c}{ sn } & \multicolumn{1}{c}{ sn } & \multicolumn{1}{c}{$\%$} & \multicolumn{1}{c}{ sn } & \multicolumn{1}{c}{$\%$} \\
\hline En küçük & 18.42 & 100 & 0.12 & 0.63 & 0.02 & 0.09 & 0.53 \\
En büyük & 260.60 & 100 & 34.68 & 13.31 & 27.25 & 10.46 & 31.20 \\
Ortalama & 136.68 & 100 & 14.43 & 10.56 & 11.70 & 8.56 & 13.26 & 9.70 \\
\hline
\end{tabular}

Çizelge 9. Toplam zamanlarının kontrol verisinden olan $(+)$ farkları

\begin{tabular}{|c|c|c|c|c|c|c|c|c|}
\hline \multirow{2}{*}{ Özellikler } & \multicolumn{2}{|c|}{ Kontrol verisi } & \multicolumn{2}{|c|}{ Kronometre } & \multicolumn{2}{|c|}{ ZÖKA } & \multicolumn{2}{|c|}{ TA } \\
\hline & sn & $\%$ & sn & $\%$ & sn & $\%$ & sn & $\%$ \\
\hline En küçük & 63.07 & 100 & 0.70 & 1.11 & 0.42 & 0.66 & 1.00 & 1.59 \\
\hline En büyük & 862.73 & 100 & 85.90 & 9.96 & 72.70 & 8.43 & 78.82 & 9.14 \\
\hline Ortalama & 460.24 & 100 & 43.59 & 9.47 & 34.91 & 7.59 & 40.21 & 8.74 \\
\hline
\end{tabular}


Çizelge 6-9' da görüldüğü gibi üç farklı zaman ölçme aracıyla yapılan ölçüm sonuçlarının, tüm iş dilimleri ölçeğinde, kontrol verisinden daha yüksek çıktığı belirlenmiştir. Kabuk soyma toplam iş zamanı ölçeğinde, kontrol verisi ile zaman ölçme araçlarına ait bulgular arasındaki göreceli farklılığın, ikili örneklem t-testine göre de istatistiksel olarak anlamlı olduğu belirlenmiştir (Çizelge $10)$.

Kontrol verisinin, video oynatıcıda çok kez izlenen görüntüler üzerinden elde edildiği dikkate alındığında; referans kabul edilen bu verinin, zaman ölçme araçlarınınkinden daha düşük (gerçek süreye daha yakın) değerlerde olması beklenen bir durumdur. Arazide, kabuk soyma işine ait fiili çalışma sürelerinin video kayıtları, tam zamanlı ve kesintisiz şekilde yapıldığından video oynatıcı programın ve bilgisayarın zaman sayacının yardımıyla ölçülen iş dilimi sürelerinin en doğru veya doğruya en yakın süreler olduğunu söylemek mümkündür. Gerek videodan görüntü analizinde gerekse üç araçla yapılan zaman analizlerinde, 1 salise (1/60 sn) hassasiyetinde ölçümler yapılabilmiştir. Nurminen vd. (2006) tarafından yapılan bir çalışmada da, video görüntülerinin analizinde, video sayaciyla $1 / 24$ sn hassasiyetinde veri elde edilebildiği belirlenmiştir. Veri hassasiyeti konusunda karşılaştırılabilir bir ölçek olması bakımından ormancılıktaki üretim makinelerine monte edilen otomatik kaydedicilerle saniyenin binde biri ölçeğinde zaman ölçümü yapılabildiği belirtilmiştir (Ovaskainen vd., 2004; Nuutinen vd., 2008). Kabuk soyma iş akışında, en kısa süreli temel çalışma zamanlarının hazırlık iş diliminde olduğu görülmüştür. Hazırlık zamanı esas alındığında, ölçülebilen en küçük süreden $(3.53 \mathrm{sn})$ olan pozitif yönlü sapmalar her üç zaman aracında da 1 sn' nin altındadır. Szewczyk ve Sowa (2017), video görüntülerinin analizleri sırasında çalışma süresi veritabanları oluşturulurken genel olarak 1 sn doğrulukla gerçekleştirilen zaman ölçümlerinin uygun standartlara karşılık geldiğini bildirmiştir. Pukkila (1959) ise odun üretiminde zaman etütleri için 2 sn' lik doğruluk seviyesi ile çalışılabileceğine işaret etmiştir. Bu çalışmada erişilen 1 sn' nin altındaki doğruluk seviyesi, veri hassasiyeti yönünden karşılaştırılabilir bir düzlem oluşturulduğunu göstermektedir. Buna göre de, yeni sayılabilecek ZÖKA uygulaması ve TA programının da kronometre gibi, zaman etütlerinde kabullenilebilir doğrulukta ölçüm yapabilen araçlar olduğu belirlenmiştir.

Çizelge 6'da da görüldüğü gibi, kontrol verisinden olan en düşük sapmanın (0.13 sn; \% 3.77), ZÖKA uygulaması ile kaydedildiği belirlenmiştir. Kronometre ve TA programının da bu ölçekte, aynı yönlü ve aynı sapma değerine (0.20 sn; \%5.66) sahip olduğu görülmüştür. Kısa süreli iş dilimlerinin gözlenmesinde; göz-el veya göz-göz koordinasyonuyla iş diliminin başlama ve bitiş noktalarının ayırt edilerek ZÖKA uygulamasının ya da TA programının butonlarına basılması veya kronometrenin komut edilmesine bağlı güçlüğün; bu sürelerin ölçümündeki sapmaları arttırdığı düşünülmektedir. Örneğin kronometre ile zaman ölçümünde göz-el, kulak-el koordinasyonu aşırı derecede önemli olduğundan (Doğan, 2015) bu çalışmada kronometre ile küçük zaman dilimlerini yakalamak oldukça güçleşmiştir. Ölçme noktalarını görerek ölçüm yapmak gerektiğinden kronometrenin ekranını okumak, tuşlarına basmak, başlatıp durdurmak, Acar ve Eroğlu (2015) tarafindan da ortaya konulduğu gibi bu çalışmada da, zaman kayıplarının kaynağı olabilir.
Çizelge 10. Kontrol verisi ile zaman ölçme araçlarının, toplam iş akışı sürelerine göre, ikili örneklem t-testi ile analizi

\begin{tabular}{lccccc}
\hline Toplam süre & Ortalama & Standart sapma & $t$ & $d f$ & $p$ \\
\hline Kontrol- & -43.592 & 20.83781 & -12.376 & 34 & .000 \\
kronometre & & 17.74311 & -11.640 & 34 & .000 \\
Kontrol-ZÖKA & -34.909 & -12.318 & 34 & .000 \\
Kontrol-TA & -40.210 & 19.31255 & -12.34
\end{tabular}

En uzun iş dilimi süresinin gözlemlendiği soyma iş akışı süresinde ölçülen en büyük değer (533.62 sn)'den olan sapmanın 45.57 sn (\%8.54; ZÖKA uygulaması) ile 55.05 sn (\%10.32; kronometre) arasında olduğu belirlenmiştir. Yaklaşık 9 dakikalık bir iş dilimi süresinin ölçülmesinde her üç araçla da 1 dakikanın altında bir sapma değeriyle karşılaş1lmıştır. Ancak üç araç, kontrol verisiyle göreceli olarak kıyaslandığında ZÖKA uygulamasının kontrol verisine en yakın; kronometrenin ise en uzak değerde sonuçlar verdiği belirlenmiştir. Buna göre, tomruk başına toplam ortalama çalışma süreleri ölçeğinde üç aracın kontrol verisinden olan farklılıklarına bakıldığında; \%11' den daha yüksek süre farklılıklarına rastlanmadığı görülmektedir. Literatürde, manuel zaman etüdü araçları ile referans kabul edilen otomatik veri kaydediciler karşılaştırıldığında ortalama zaman ölçüm değerlerinde \% 8 ile \% 38 arasında sapmanın olabileceği belirtilmiştir (Nordén ve Granlund, 2003; Nuutinen vd., 2008). Bu çalışmadaki zaman ölçme araçlarının, kontrol verisinden olan sapma miktarlarının kabul edilebilir seviyede olduğu söylenebilir. Bununla birlikte, ZÖKA uygulamasının hem kısa süreli iş dilimlerinde hem de uzun süreli iş dilimlerinde daha hassas veri ölçümü ve kaydı yaptığı belirlenmiştir. Tomruk başına kabuk soyma iş dilimi sürelerinin uzun olması durumunda (soyma temel zamanı gibi), zaman ölçme araçlarının performansları arasındaki farklılığın oldukça azaldığı da tespit edilmiştir.

$\mathrm{Bu}$ çalışmada sınanan üç araçla ölçülebilen tomruk başına en küçük iş dilimi süresi, 3.67 sn olarak kaydedilmiştir. Ormancılıkta, Acar vd. (1997) tarafından odun hammaddesinin sürütülmesi için kronometreyle yapılan zaman etüdünde en küçük zaman değeri, 3 sn olarak ölçülmüştür. Pukkila' nın (1959) yaptığı bir çalışmada analog kronometre ile ölçülebilen en kısa iş dilimi süresi 2 saniye olarak belirlenmiştir. Ölçülen iş dilimi süresi ile hiç ölçülmemiş iş dilimi arasında bir ilişki bulunmakta olup etütçünün 2 saatten uzun süreli manuel zaman ölçümlerinde hata yapma olasılığı artmaktadır (Pehkonen, 1978; Spinelli vd., 2013). Güvenilir ve hassas bir zaman etüdü yapılabilmesi için manuel yöntemlerle gerçekleştirilen zaman ölçümlerinde, seçilen araç ve teknik, ortaya çıkabilecek olası hatalar üzerinde oldukça etkilidir (Harstela, 1991). Sowa (2009), odun üretiminde motorlu testere ile kesim işlerinde 6 sn' den kısa süreli iş dilimlerinin klasik yöntemlerle ölçülemeyeceğini belirtmiştir. Nuutinen vd. (2008), zaman ölçümlerinde hata kaynaklarının etkilerini belirlemek için yaptığ 1 çalışmada, 4 sn' den kısa süreli iş dilimlerinin ölçülmesinde manuel zaman ölçme tekniklerinin başarısız olduklarını ortaya koymuş ve hassas veri toplamaya yarayacak bir veri kaydedicinin varlığına ihtiyaç olduğunu işaret etmiştir. Aykut (1972), desimal dakika taksimatlı kronometre, Wink sayıcısı ve Marsto - Chron adlı 3 aracı karşılaştırdığ 1 çalışmasında; Marsto - Chron'un 3 sn' den daha kısa süreli 
iş dilimi sürelerinin ölçülmesinde; kronometrenin 3 sn' nin üzerindeki iş dilimi sürelerinin ölçülmesinde, Wink sayıcısı adlı aracın ise $1.8 \mathrm{sn}$ ' den daha uzun süreli iş dilimlerinin ölçülmesinde kullanılabileceğini belirlemiştir. Bununla birlikte, kısa süreli iş dilimi zamanlarını ölçebilen araçların hassasiyetinin de yüksek olabileceği ve daha az tekrarlı ölçmelerin istenilen sonuca erişmede yeterli olabileceği ortaya konulmuştur. $\mathrm{Bu}$ nedenle, etütçüyü yormayacak ve kısa iş dilimi sürelerini ölçebilecek pratik bir zaman ölçmekaydetme aracının gerekliliği ortaya çıkmaktadır. Kontrol verisindeki en kısa süreli iş dilimine en yakın sonucu veren araç ZÖKA uygulaması olduğundan bu uygulamanın kısa süreli iş dilimlerinde daha hassas veri ölçme ve kaydı yaptığını söylemek mümkündür. Bununla birlikte hem kısa süreli hem de uzun süreli iş dilimi zamanlarının ölçülmesinde TA programının dijital kronometreye göre daha hassas ölçme yaptığı söylenebilir.

Üç zaman ölçme aracıyla elde edilen zaman verileri arasındaki farklılıkların anlamlı olup olmadığını istatistiksel olarak ortaya koymak için eşleştirilmiş ikili örneklem t-testi uygulanmış ve elde edilen bulgular Çizelge 11' de özetlenmiştir.

Zaman ölçüm araçlarının kendi aralarındaki ikili karşılaştırmalardan anlaşıldığı kadarıyla (Çizelge 11); kabuk soyma sürecinin iş dilimlerinin ölçülen toplam zaman değerleri arasındaki farklılığın istatistiksel olarak $(p<0,01)$ anlamlı olduğu tespit edilmiştir. Aynı operatör ve aynı iş üzerinde aynı etütçü tarafından yapılan zaman analizlerinin sonucunda; kronometre, TA programı ve ZÖKA uygulamasının ölçtüğü süreler arasında anlamlı bir farkın olması, her üç aracın da birbirlerinden farklı bir hassasiyete sahip olduğu yargısını desteklemektedir.

Zaman etütlerinde en çok kullanılan ölçme aracının kronometre olduğu dikkate alındığında, ZÖKA uygulaması ile tomruk başına toplam ortalama kabuk soyma süresi ölçeğinde, kronometreye göre \% 2 (8.68 sn) daha hassas ölçme yapılabilmiştir. En kısa süreli iş diliminde tomruk başına ölçülebilen en küçük süre ölçeğinde, ZÖKA uygulamasıyla, kronometreden yaklaşık \% 4 (0.15 sn) daha hassas ölçüm gerçekleştirilebilmiştir (Çizelge 11). Toplam ortalama kabuk soyma süresi ölçeğinde TA programı da kronometreden \%1 (3.38 sn) daha hassas sonuçlar vermiştir. Aynı iş dilimi için ZÖKA uygulamasıyla da, TA programından $\% 1 \quad(5.30 \quad \mathrm{sn})$ daha hassas ölçüm yapılabilmiştir. Ancak en kısa süreli iş diliminin en küçük değeri ölçeğinde ZÖKA uygulamasıyla, TA programından \% $2.7(0.10 \mathrm{sn})$ daha hassas süre ölçülebilmiştir. Vaatainen vd. (2003), ağaç kesim sürecinde hasat makinesinin çalışma zamanlarının ölçülmesinde; el bilgisayarı ile otomatik veri kaydedicinin performansını karşılaştırmış ve el bilgisayarı üzerinden manuel yöntemle yapılan zaman ölçüm hatasının 0.367 - 0.599 sn arasında olduğunu belirlemiştir. Bu çalışmada da, kısa süreli iş dilimlerinin tomruk başına en küçük zaman değerlerinin ölçümünde ZÖKA uygulaması ve TA programiyla, kronometreye göre sirasıyla 0.15 sn ve 3.30 sn daha düşük değerlerin ölçülebilmesi, her iki yeni aracın da veri hassasiyeti açısından kabul edilebilir sınırlar içinde olduğunu göstermiştir. Kronometreyle beraber ZÖKA uygulaması ve TA programının da zaman etütlerinde kullanılabileceği ancak kısa süreli iş dilimlerine sahip iş akışlarının ölçülmesinde ZÖKA' nın veri hassasiyeti bakımından daha üstün özellikler sunabileceği belirlenmiştir. Buna rağmen, etütçülerin zaman ölçümlerinde bu üç araçtan hangisini tercih edecekleri, bu araçların kullanılabilirliklerine ilişkin bir değerlendirmeyle belirlenebilir.

\subsection{Zaman ölçme araçlarının kullanım özelliklerinin karşılaştırılması}

$\mathrm{Bu}$ çalışmada gerçek çalışma zamanına en yakın değerleri veren video analizi sonuçlarının, kontrol verisi olarak kullanılması; bu yönteminin (bu çalışma kapsamındaki diğer araçlara göre) hassas bir yöntem olduğunu gösterse de, bundan sonraki iş-zaman etütlerinde video kayıt-görüntü analizinin kesinlikle tercih edilmesi gerekliliğini dikte etmez. Çünkü video analizine dayalı zaman etütlerinde hem sahada veri toplamak hem de büroda iş dilimlerine ait çalışma sürelerini ölçüp analiz etmek için harcanan süre ve emek artmaktadır (Walczyk vd., 2009; Smidt ve McDaniel 2012; Borz vd., 2015). Bu yüzden sahada pratik ve kolaylıkla kullanılabilen zaman ölçme araçlarıyla çalışılması ihtiyacı, önemini sürdürmektedir (Spinelli vd., 2013). Sahada zaman etütleri sırasında da, kısa süreli iş dilimlerinin zamanlarını ölçmek oldukça zor olduğundan, tercih edilecek ölçme aracının hassas olması yanında kullanım kolaylığı sunması gerekmektedir (Pehkonen, 1978).

Android işletim sistemine sahip akıllı cep telefonunda çalışan ZÖKA uygulamasıyla, ek araç ve gereçlere ihtiyaç duyulmadan istenilen anda zaman etüdü yapılabilmiştir. Bu uygulama istenildiğinde, android tabanll tablet gibi diğer mobil cihazlarda da kullanılabilir. Verilerin kayıt edilmesi işlemi, sadece bir butona komut vererek MS Excel programı formatında hızlı ve kolay bir şekilde gerçekleştirilmiş ve veri aktarımı (kablolu veya kablosuz yollarla) yapılabilmiştir. Uygulamada bulunan 12 adet zaman ölçüm butonunun isimlendirilebilir olmasından dolayı zaman etüdünde kullanım kolaylığı elde edilmiştir. ZÖKA uygulaması bu çalışmada kümülatif zaman ölçme tekniği (Yıldırım, 1989) ile kullanılmasına rağmen tekrarlı zaman ölçme tekniğine de uygundur. Çünkü uygulamadaki zaman sayaçları her türlü iş dilimi süresinin ölçülmesine uygun olup iş yeri süresi, çevrim süresi, sefer süresi, yan faaliyet ve ek faaliyet sürelerini de (Magagnotti ve Spinelli, 2012), ölçüp kaydedebilecek kapasitedir. ZÖKA uygulamasının en büyük avantajlarından biri, birkaç saniye ölçeğinde iş dilimlerinin gözlenmesi ve ölçülmesi için başarılı şekilde kullanılabiliyor olmasıdır. Zaman ölçümü sırasında göz-el (Doğan, 2015) koordinasyonuna dayalı bir ölçme taktiği uygulanmıştır. Bu nedenle etütçü koordinasyon için daha az enerji ve dikkat sarf ederek çalışma hızı kazanmıştır. Geliştirilen bu uygulamanın kullanışlılığının, mobil cihazın niteliğine bağlı olduğu belirlenmiştir. Çünkü cihazın batarya durumu, hafizası, ısınmadan kaynaklı takılmaların meydana gelmesi gibi aksaklıklara bağlı olarak çeşitli çalışma hatalarının ortaya çıkabileceği gözlenmiştir.

Çizelge 11. Kabuk soyma toplam iş akışı sürelerine göre üç farklı aracın ikili örneklem t-testi ile karşılaştırılması

\begin{tabular}{lccccc}
\hline Toplam süre & Ortalama & Standart sapma & $t$ & $d f$ & $p$ \\
\hline Kronometre-ZÖKA & 8.682 & 3.88814 & 13.211 & 34 & .000 \\
TA - ZÖKA & 5.300 & 2.64525 & -11.855 & 34 & .000 \\
Kronometre-TA & 3.381 & 2.44329 & 8.188 & 34 & .000 \\
\hline
\end{tabular}


Zaman ölçme ve kaydedebilme, sonrasında da analiz ve raporlama imkanlarına sahip olacak şekilde masaüstü ve dizüstü bilgisayarlarda kullanılmaya elverişli olan TA programının (Yılmaz, 2015), fonksiyonel ve profesyonel bir yapıda olduğuna kanaat getirilmiştir. Veri kaydedilmesi otomatik olarak yapıldığından veri aktarımında doğabilecek hatalar ortadan kaldırılmıştır. Zaman ölçümü sırasında veya hemen sonrasında verilerin hızlı ve kolay bir şekilde işlenmesine olanak sağlanmaktadır. Elde edilen verileri başka bir cihaza aktarmadan veriler gözlemlenebilmekte veya işlenebilmektedir. Kayıt miktarı, kullanılan bilgisayarın depolama kısmının kapasitesine göre değişmekle birlikte çok fazla veri kayıt edilebilmesine olanak sağlayan zaman ölçüm aracıdır. Ancak çalışma sırasında, etüt edilen iş dilimlerini izleme ile programı kullanma arasında yüksek derecede koordinasyonun (eş güdümün) sağlanması gerektiği tespit edilmiştir. Etütçünün ölçüm sırasında cihaza bağlı ek araçlar (fare, klavye, vb.) kullanması gerektiğinden kaba ölçüm hatalarının ortaya çıkma potansiyeli bulunabilmektedir. Etütçünün zaman ölçümü yapmadan önce program üzerinde eğitim alması, pratik yapması ve de komut sistemini öğrenmesi gerekmektedir.

Zaman ölçümlerinde şu anda kullanılmakta olan en yaygın araç olan kronometre (Koŝir et al., 2015); etüt formu ve tablasıyla birlikte kullanılmıştır. Zaman ölçümlerinde etütçü sürekli çalışanı ve/veya makineyi ya da yapılan işi gözlemek, ölçme noktalarını takip etmek, kronometre butonlarına komuta etmek ve aynı zamanda ekranı okuyup etüt formuna not almak zorunda kalmıştır. Çalışma kapsamında, tekrarlı zaman etütlerinin denenmesi sırasında, kronometrenin durdurulup yeniden başlatılması gerektiğinden zaman kayıpları oluşmuştur. Kronometre ile zaman ölçümünde birden fazla araç kullanılması gerektiğinden hem büro hem de arazi şartlarında etütçü olumsuz yönde etkilenmiş; okuma ve aktarma hataları ortaya çıkmıştır. Bundan dolayı, kronometre ve etüt tablasıyla çalışma, kullanıcı açısından ergonomik bulunmamıştır. Ayrıca verilerin, işlenebilmesi için sayısal ortama tek tek aktarılması gerektiğinden etüt ve analiz zamanı uzamıştır.

Teknik açıdan ana ekran ve arayüz yapısı gelişmiş olan zaman ölçüm aracının, TA programı olduğu ortaya çıkmıştır. Ancak ara yüz bakımından ilk kullanıcıya karmaşık gözükmesi ve iş akış şekilleri incelendiğinde ölçüm yapan gözlemcinin iş yükünü arttırması, zaman ölçümlerinde hataların ortaya çıkma riskini de taşımaktadır. TA programının diğer zaman ölçüm araçları ile kıyaslandığında en önemli farkı; elde edilen verilerin doğrudan depolanması, işlenmesi, aktarılması ve paylaşılmasını daha hızlı yapma imkânına sahip olmasıdır.

Arazi şartlarında kullanışlılığ uygulaması öne çıkmaktadır. Tek elle kullanıma uygun, basit ve ergonomik bir yapıya sahip olan ZÖKA uygulaması iş sağlığı ve güvenliği açısından tehlikeli durumların algılanması için etütçüye firsat sunabilir ve etütçünün tehlikeli davranışlar sergilemesini gerektirmeyebilir. Diğer zaman ölçüm araçları çift el ile kullanım gerektirmekle birlikte göz - göz, göz - el ve göz - kulak koordinasyonu gerektirdiği için arazi şartlarında kullanımında zorluklar meydana gelebilir.

Yıldırım (1989) zaman ölçümünde, veri toplama araçlarının sahip olması gereken özellikleri; 1) zaman değerlerini otomatik olarak kaydedebilmeli, 2) kayıt sistemi, iş akış dilimi sürelerinin düzeltilmesine uygun olmalı, 3) orman işlerinin özelliği ve uzun süreli çalışma gereği akülü/bataryalı olmalı, 4) arazi şartlarında kullanımına uygun ve dayanıklı olmalı, şeklinde sıralamıştır. Bu özellikler itibariyle ZÖKA uygulamasının bütün bu gereklilikleri karşılayabilecek nitelikte olduğunu iddia etmek mümkündür.

\section{Sonuç ve öneriler}

Ormancılık işlerinde çeşitli amaçlar için zaman etütlerinin yapılmasına gereksinim duyulmaktadır. Beden gücü ağırlıklı ve yarı mekanize işlerde; işyerinde temel iş sürelerinin doğrudan gözlemlerle ölçülmesi manuel zaman ölçüm teknikleri ve araçlarıyla gerçekleştirilmektedir. Toplanan zaman verisinin hassasiyetinin arttırılması, zaman ölçüm işlerinin kolaylaştırılması ve çeşitli ölçüm hatalarının bertaraf edilmesi için doğrudan ya da dolaylı zaman etüdü yöntemlerinde kullanılmak üzere teorik ve teknik yönden uygulanabilirliği ispatlanmış, bilgisayar (işletim sistemi) destekli zaman ölçme ve kaydetme aracı olan TA programı ile android tabanlı ZÖKA uygulaması geliştirilmiştir. Bu çalışmada hem birbirleriyle hem de kronometre ve kontrol verisiyle hassasiyet ve kullanım özellikleri bakımından karşılaştırılması yapılan bu iki zaman ölçme aracı, ormancılık uygulamalarında yaygın ve etkili şekilde kullanılabilecek niteliktedir.

Video görüntü analizleriyle elde edilen referans verilerinden olan sapmalara göre; ZÖKA uygulaması, TA programı ve dijital kronometreden daha hassas ölçüm yapabilen ve kaydedebilen bir araçtır. TA programı da veri hassasiyeti ve kaydı açısından kronometreye göre daha üstün niteliklere sahiptir. $\mathrm{Bu}$ araçlarla yapılan zaman ölçümlerinden elde edilen sonuçlar; hem kısa süreli hem de uzun süreli iş dilimleri ölçeğinde, gerçek çalışma sürelerine çok yakındır. $\mathrm{Bu}$ yönüyle, kronometreler yanında bu araçların da zaman etütlerinde kullanılması, zaman ölçme işlerinin kolaylaştırılması ve hassaslaştırılmasına firsat sunacaktır.

Zaman etüdünde, 3 sn' nin altında zaman aralıklarına sahip iş dilimlerini ölçmek ve kaydetmek gerekli ise, o zaman android tabanlı yazılımla üretilmiş ZÖKA uygulaması kullanılabilir. Etütçü gözlerini iş ve çalışandan ayırmadan ve ölçme cihazına bakmaksızın herhangi bir iş diliminin ölçme noktalarını, mobil bir telefon veya benzeri cihazın dokunmatik ekranı üzerindeki iki butona, göz-el veya kulak-el koordinasyonunda, parmakla dokunarak ölçüp kayıt edebilecektir.

Zaman ölçümünün hassas şekilde yapılması yanında elde edilen verinin kaydedilmesi, işlenmesi, analiz edilip sunulması gibi işlevleri olan veri tabanı kayıt sistemine sahip; windows veya android işletim sistemli mobil cihazlarda çalışabilen TA programı ve ZÖKA uygulaması; uygulanabilirlik, kullanışlılık ve erişilebilirlik açısından uygun birer zaman ölçüm aracıdır.

Bir defada etüt edilen iş miktarı, gözlem sayısı, etüt süresi, elde edilen verilerin aktarımı, paylaşımı, depolanması ve gerektiğinde verilerin işlenme hızı ve doğruluğu açısından ZÖKA uygulaması ve TA programı makul sonuçlar ortaya koyabilmiştir. Ancak bu uygulama ve programın çalıştırıldığı cihazların pil (batarya) ve bellek (hafıza) özelliklerinin veri kaydı ve depolanması işlemlerini farklılaştırabileceği göz önünde bulundurulmalıdır. Bununla birlikte hem ZÖKA uygulamasının hem de TA programının 
yapısal mimarisinin eksik noktalarının kontrol edilip giderilmesi ve daha gelişmiş bir ara yüze dönüştürülmesi halinde arazi şartlarında gerek duyulan zaman ölçüm araçlarına olan ihtiyacı tamamıyla giderebilir.

\section{Açıklama}

Bu çalışmanın gerçekleştirilmesinde, Prof. Dr. Mehmet EKER danışmanlığında, SDÜ Fen Bilimleri (Isparta Uygulamalı Bilimler Üniversitesi Lisansüstü Eğitim) Enstitüsü'nde Yasin KURT tarafından hazırlanan Yüksek Lisans tezinden yararlanılmıştır. İlgililere teşekkür ederiz.

\section{Kaynaklar}

Acar, H.H., Aykut T., Şentürk, N., 1997. Artvin yöresinde bölmeden çıkarmada kullanılan Koller K 300, Urus M III ve Gantner Tipi hava hatlarının karşılaştırılması üzerine bir araştırma. İstanbul Üniversitesi Orman Fakültesi Dergisi, 47(2): 29-58.

Acar, H.H., Eroğlu, H., 2015. Ormancılık İş Bilgisi ve İş Güvenliği, KTÜ Orman Fakültesi, Yayın No: 235/41, Trabzon.

Aykut, T., 1972. Zaman etütlerini yapılmasında kullanılan aletler ve metotlar. İ.Ü. Orman Fakültesi Dergisi, 1(B): 17-32.

Barnes, M.R., 1963. Motion and Time Study: Measurement of Work, John Wiley and Sons, INC, Fifth Edition, New York, London, Sydney.

Berkel, A., 1976. Ormancılıkta İş Bilgisi, İ.Ü. Orman Fakültesi Yayın No: 220, İstanbul.

Björheden, R., 1991. Basic time concepts for international comparisons of time study reports. Journal of Forest Engineering, 2(2): 33-39.

Borz, SA, Ignea, G, Popa, B, Spârchez, G, Iordache, E., 2015. Estimating time consumption and productivity of roundwood skidding in group shelterwood system - a case study in a broadleaved mixed stand located in reduced accessibility conditions. Croatian Journal of Forest Engineering, 1:137-146.

Doğan, A., 1998. Yönetebilmenin en önemli arac1: İş etüdü. Anahtar Dergisi, 10(117):8-21.

Doğan, A., 2015. İş Etüdü Yöntem Bilgisi. Türkiye Cumhuriyeti Bilim, Sanayi ve Teknoloji Bakanlığı Verimlilik Genel Müdürlüğü, Ankara.

Eker, M., 2015. Asli Orman Ürünlerinin Üretim İşlerinde İş-Zaman Analizlerinin Yapılması ve Standart Zamanların Hesaplanması. Orman Genel Müdürlüğü Üretim İşlerinde İş-Zaman Analizleri Projesi (Yayınlanmamış), Isparta.

Eker, M., Özer, D., 2015. Üretim işlerinde hassas ormanc1lik yaklaşımı. Türkiye Ormancılık Dergisi, 16 (2): 183-194.

Eker, M., Kurt, Y., 2019. Ormanc1lık işlerine yönelik bir zaman ölçme ve kaydetme aracının geliştirilmesi. Türkiye Ormancılık Dergisi, 20(3): 157-167.

Eker, M., Şefik, M., 2019. Motorlu tırpana montajlı kabuk soyma aracının (motosoyar) geliştirilmesi ve denenmesi. Türkiye Ormancilık Dergisi, 20(4): 411-420.

Eliasson, L, Hofsten, H, Johanesson, T, Spinelli, R, Thierfelder, T., 2015. Effects of sieve size on chipper productivity, fuel consumption and chip size distribution for open drum chippers. Croatian Journal of Forest Engineering, 1:11-18.

Gülci, N., Erdaş, O., Akay, A.E., 2015. Üretim işlerinde hassas ormancılık yaklaşımı. Üretim İșlerinde Hassas Ormancılık Sempozyumu, 4-6 Haziran, Ilgaz, s. 238-256.

Harstela, P., 1988. Principle of comparative time studies in mechanized forest work. Scand. J. For. Res. 3: 253-257.

Harstela, P., 1991. Work studies in forestry. Silva Carelica, 18:41.

ILO, 1981. Introduction to work study. International Labour Office, Geneva, Switzerland.

Kanawaty, G., 2004. İş Etüdü. MPM Yayınları, No:29, Ankara.

Kariniemi, A., 2006. Kuljettajakeskeinen hakkuukonetyön malli työn suorituksen kognitiivinen tarkastelu. Helsingin yliopiston metsävarojen käytön laitoksen julkaisuja 38:126 p.
Kellog L., Davis, C., Bolding, C., 2004. Measuring machine productivity with a multi_dat data logger; a demonstration on three forest machines. Oregon State University, Department of Forest Engineering, USA, http://www.cof.orst.edu/cof/ferm/ research/krg/WR-COFE-\%2005.pdf, Accessed :18.06.2019.

Kosiir, B., Magagnotti, N., Spinelli, R., 2015. The role of work studies in forest engineering: status and perspectives, International Journal of Forest Engineering, 26(3):160-170.

Kurt, Y., 2019. Odun üretim işlerinde kullanılan zaman ölçüm metotları ve araçlarının değerlendirilmesi. Yüksek lisans tezi, Isparta Uygulamalı Bilimler Üniversitesi, Lisansüstü Eğitim Enstitüsü, Isparta.

Laforest, S.M., Pulkki, R., 2011. Case study of integrating onboard computers in northern Ontario's forest supply chains. Proceedings of 34th Council on Forest Engineering, 12-15 June, Quebec City, 13 p.

Leech, J.W., Sutton, M.W., Archer, G.R., 1989. Recording field measurements on Husky Hunter microcomputers. Australian Forestry, 52(2): 68-73.

Magagnotti, N., Spinelli, R., 2012. Good practice guidelines for biomass production studies, european cooperation in science and technology, COST Action FP-0902, 50 p., Italy.

McDonald ,T., Fulton, J., 2005. Automated time study of skidders using global positioning system data. Computers and Electronics in Agriculture, 48:19-37.

MPM, 1991. İşletmelerde Verimlilik Denetimi, Ölçme ve Değerlendirme Modelleri. Milli Prodüktivite Merkezi Yayınları, No: 435, Ankara.

MPM, 1997. İş Etüdü. Milli Prodüktivite Merkezi Yayınları, Yayın No:29, Ankara.

Nakagawa, M., Hamatsu, J., Saitou, T., Ishida, H., 2007. Effect of tree size on productivity and time required for work phases in selective thinning by a harvester. Int. J. For. Eng., 18(2):24-28.

Nordén B., Granlund, P., 2003. Horisontering av förarstolen ökar skördarens prestation - även I relativt flack terräng. Skogforsk 1, $63 \mathrm{p}$.

Nurminen, T., Korpunen, H., Uusitalo, J., 2006. Time consumption analysis of the mechanized cut-to-length harvesting system. Silva Fennica, 40(2):335-363.

Nuutinen, Y., Väätäinen, K., Heinonen, J., Asikainen, A., Röser, D., 2008. The accuracy of manually recorded time study data for harvester operation shown via simulator screen. Silva Fennica, 42(1): 63-72.

Ovaskainen, H., Uusitalo, J., Väätäinen, K., 2004. Characteristics and significance of a harvester operators' working technique in thinnings. International Journal of Forest Engineering, 15(2):67-77.

Ovaskainen, H., 2009. Timber harvester operators' working technique in first thinning and the importance of cognitive abilities on work productivity. Ph.D. thesis, University of Eastern Finland, Joensuu, Finland.

Palander, T., Nuutinen, Y., Kariniemi, A., Vaatinen, K., 2013. Automatic time study method for recording work phase times of timber harvesting. Forest Science, 59(4):472-483.

Pehkonen, A., 1978. Accuracy of timing in some time study methods. Journal of the Scientific Agricultural Society of Finland, 50(1): 66.

Peltola, A., 2003. IT-time for mechanised forest work study. Proceedings of 2nd Forest Engineering Conference, 12-15 May, Växjö, Sweden, pp.107-112.

Pukkila, A., 1959. Työntutkimus (Job Researches). Otava, Helsinki.

Purfürst, FT, Erler, J., 2011. The human influence on productivity in harvester operations. International Journal of Forest Engineering, 2:15-22.

REFA, 1988. İş Etüdü Yöntem Bilgisi: İş Etüdünün Temelleri. MPM Yayınları, Yayın No:544, Ankara.

Smidt, M.F., McDaniel, J., 2012. Utilization, cost, and landowner return from whole-tree chipping young loblolly pine thinnings. Croatian Journal of Forest Engineering, 2: 211-223. 
Sowa J.M., 2009. Współczesne pożytki z lasu. In: Starzyk R.J. (ed.). Leśnictwo w górach iregionach przemysłowych. Wydawnictwo Uniwersytetu Rolniczego w Krakowie, Kraków. pp. $129-152$.

Sowa J.M., Szewczyk G., 2013. Time consumption of skidding in mature stands performed by winches powered by farm traktor. Croatian Journal of Forest Engineering, 2: 255-265.

Spinelli, R., Visser, R., 2008. Analyzing and estimating delays in harvester operations. Int. J For. Eng., 19(1):36-41.

Spinelli, R., Laina-Relaño, R., Magagnotti, N., Tolosana, E., 2013. Determining observer and method effects on the accuracy of elemental time studies in forest operations. Baltic Forestry, 19(2):301-306.

Szewczyk G., Sowa J. M., Grzebieniowski W., Kormanek M., Kulak D., Stańczykiewicz A., 2014. Sequencing of harvester work during standard cuttings and in areas with windbreaks. Silva Fennica, 48 (4):1-16.

Szewczyk, G., Sowa, J.M., 2017. The accuracy of measurements in a time study of harvester operations. N.Z. j. of For. Sci., 47: 24.
Üçüncü, K., 2005. Ergonomi ve İs Etüdü. Orman Fakültesi, Orman Endüstri Mühendisliği Bölümü Ders Notları, No:77, K.T.Ü. Basımevi, Trabzon.

Üçüncü, K., Acar, H.H., 2020. Ergonomi. Nobel Akademik Yayınc1lı, İstanbul.

Vaatainen, K., Ovaskainen, H., Asikainen, A., Sikanen, L. 2003. Chasing the tacit knowledge - automated data collection to find the characteristics of a skillful harvester operator. Proceedings of 2nd Forest Engineering Conference 12-15 May, Växjö, Sweden, pp. 3-10.

Walczyk, J, Kormanek, M, Walczykova, M., 2009. Videocomputer technique in determining of the skidding tractors soil-wheel contact area. In A Skoupy (Ed.), Krajina, les a lesni hospodáŕstvi [Landscape, forests and forestry], Prague: Česká Zemědělská Univerzita v Praze, pp. 292-299.

Yıldırım, M., 1989. Ormancılık İş Bilgisi. İstanbul Üniversitesi Orman Fakültesi Yayınları, İstanbul.

Yılmaz, K., 2015. Zaman analizlerine yönelik zaman etüdü kayıt programının oluşturulması. Lisans Bitirme Tezi, Süleyman Demirel Üniversitesi, Orman Fakültesi Orman Mühendisliği Bölümü, Isparta. 